\title{
Constellations of Memory: The Historicity of Hungarian Yizker-Bikher
}

\author{
Lujza Vallo
}

\begin{abstract}
The following paper reviews Central Eastern European memorial volumes created within the borders of modern-day Hungary from the 1960s onwards. Using six non-consecutively chosen primary sources as the subjects of analysis, the argument of this piece will centre around finding out whether memorial volumes or in Yiddish yizker-bikher are reliable testimonial documents based on their historical veracity. The paper argues that the historicity of Central Eastern European memorial books can range from personal tales of community living, to more traditional historical monographs, aiming to fill out gaps in trans-generational remembrance. The analysis is then divided into three chapters, each introducing a relevant perspective when evaluating yizker-bikher: Firstly, it will examine the six memorial books as linguistic sources by showcasing their characteristic narrative techniques. Secondly, the paper will contrast the historical contents covered in the texts with the findings of modern Hungarian Holocaust research. Thirdly, previous academic perspectives categorising yizker-volumes are introduced, leading the paper to a brief conclusion. A final evaluation is conducted to highlight the examined volumes as sources of microhistory that carry anthropological research potential rather than the ability to provide overarching solutions to the questions of contemporary Holocaust historiography.
\end{abstract}

Keywords

Holocaust history, memorial volumes, Hungary, Yizker-bikher 


\section{Introduction}

The following essay examines six unique volumes of Hungarian Jewish memorial literature, also known as yizker-bikher, based on their narrative techniques and their ability to provide historical evidence for researching the Hungarian Holocaust. The essay argues that memorial volumes are to be evaluated as important pieces of testimonial literature and carriers of microhistory. To demonstrate this, the paper covers three different angles that may factor into evaluating yizker volumes as valuable sources for historical research. The three angles that constitute the structure of the essay are the following: first, linguistic style, second the historical content covered, and finally, changing perspectives on historical veracity.

Jewish memorial volumes or yizker-bikher [sing. Yizker-bukh] are memory books published by Eastern European Holocaust survivors of a given community from the 1940s onwards. Yad Vashem had estimated the number of volumes to be around twelve hundred, which altogether represent at least forty-five hundred communities from all around Eastern Europe. Yizkerbikher are usually edited by a nominated group of survivors born inside the community and are produced by landsmanshaftn, which were the mutual aid societies of immigrants usually based in Israel or the United States. ${ }^{1}$ These books were and are created out of communal effort, involving many different authors in the writing process: survivors of a specific community were called on to submit short diary entries, letters, photographs, and any relevant document or text that would appropriately commemorate their pre-war life in the village or city from where they were deported. Yizker-bikher, in almost all cases, feature long lists of names commemorating the victims that were murdered in ghettos, killing centres, or by Einsatzgruppen. Though yizker volumes are not monographs, it was common for landsmanshaftn to commission a single historian or writer to edit and organise the memory book. This practice has become more regular from the 1980s onwards, though there are disagreements among historians whether these pieces should be evaluated as yizker volumes or simply historical monographs. Yizkerbikher tend to follow a similar structure, usually inspired by the chronology of the history they cover: the life of the community before WWII, the Jewish community's experience during the Holocaust, the post-war immigrant communities of survivors, and eventually a necrology for the victims of the community. ${ }^{2}$

Yizker-bikher are also representative of a long-standing narrative tradition in both Eastern European and Jewish culture. Different genres and forms of memorial literature have been common practices for commemorating loss both in the religious texts of Judaism, as well as Eastern European arts. The titling of a yizker-bukh is reliant on the book's aims and purposes. Historians Jack Kugelmass and Jonathan Boyarin divide yizker-bikher into different categories based on intertextual references to other genres within the title: sefer, pinkes, and le-kedoshey. The category of sefer (e.g Sefer zikaron li-Yehude Derets'keh u-gelilothea or in English Derecske Memorial Volume) denotes an organised collection of holy texts that were created for religious purposes. In the case of a yizker-bukh the word sefer is then used to sanctify the volumes'

\footnotetext{
1 Joshua Shanes, "Memorybooks", in The Routledge Companion To Jewish History And Historiography (London: Routledge, 2018), pp. 446-450, p. 446.

2 Joshua Shanes, "Memorybooks", p. 447.
} 
mission and purpose, as well as to evoke biblical allusions. Pinkes (e.g: Pinkes fun der shțt Pruzhene or Pruzhana Memorial Book) means a specific memorial volume that was a collectively made substitute for the lost town or village chronicle. The final group of volumes is le-kedoshey (e.g: Mea shana le-yehudei Debrecen; le-zekher kedoshei ha-kehila ve-yishuvei haseviva or One Hundred Years of the Jews of Debrecen: In Memory of the Martyrs of Debrecen and its Environs), which categorises the book as a text dedicated to the martyrs of the community who have perished during the Holocaust. ${ }^{3}$

\footnotetext{
3 Jack Kugelmass and Jonathan Boyarin, From A Ruined Garden: The Memorial Books Of Polish Jewry (Bloomington: Indiana University Press, 1998), p. 2.
} 


\section{Selection of Yizker Volumes}

Before moving onto the analysis of the linguistic aspects of memorial volumes, it is important to look at the specific cases of the six yizkers discussed here. The first and oldest yizker, published in Tel Aviv in 1966, comes from the East-Hungarian town of Csenger. Csenger's memorial volume, Jizkor-Könyv Csenger Porcsalma És Vidéke Mártírjainak Emlékére [Yizker Book in Memory of the Martyrs of Csenger Porcsalma and its Region] relates the story of a small, rural and deeply religious Jewish community based in the most Eastern corner of modern-day Hungary. This volume predominantly focuses on Csenger and its environs' religious development in order to outline the cultural, religious losses the community had suffered. This yizker is perhaps the closest to what Boyarin and Kugelmass categorise as a sefer. Published in Haifa, 1970, the second oldest yizker, A Debreceni Zsidók Száz Éve: A Mártírhalált Halt Debreceni És Környékbeli Zsidók Emlékére [One Hundred Years of the Jews of Debrecen: In Memory of the Martyrs of Debrecen and its Environs] discusses a locality from the same region of the country. Debrecen's volume centers its narrative around the general intellectual history of the county seat, emphasising the strength and prestige of Jewish schools and their high educational standards. The third volume, Az Újpesti Zsidóság Története [The History of Újpest Jewry] (Tel Aviv, 1975) focuses on similar thematics. It embraces Újpest's physical and cultural closeness to the capital and its prosperous intelligentsia with the attempt of reconstructing a part of Jewish Budapest. Újpest's yizker, similarly to Debrecen's, describes the roots and development of a strongly urbanised, innovative Jewish community that held onto its traditions despite the influence of the modern city. The fourth volume, Derecske És Vidéke Zsidósága [The Jewry of Derecske and its Environs], published in Tel Aviv in 1984, is another example of the documentation of rural Jewish life in East-Hungary before WWII. Derecske's volume is a more conversational, personal work that paints an idyllic picture of Jewish and gentile coexistence in the countryside. The final two volumes are the English language Bonyhád: A Destroyed Community (New York, 1994) and the multilingual Emlékezz: Székesfehérvár És Környéke Zsidósága [Remember: The Jews of Székesfehérvár And Its Environs] (Jerusalem, 1997). Bonyhád's memory book came about as the work of a single historian paying homage to the small, once close-knit Jewish community he grew up in, located in the Southwestern part of Hungary. The most recent publication is Székesfehérvár's volume originating from a larger city in Northwestern Hungary. Though different in scope, these two yizker-bikher attempt to portray their locations' history with as much historical accuracy and detail as possible: they tend to adhere to available archival data, as well as personal or community memory.

The six volumes covered here are all part of the British Library's memorial volume holdings and originate from within the borders of modern-day Hungary. ${ }^{4}$ Importantly, not all available sources included in the British Library's collection are covered in this essay, due to limited research abilities and lack of access to physical copies as a consequence of the COVID-19 restrictions. The towns and cities discussed here are not organised by order of importance or size and are located in different parts of the country. The methodology for choosing and evaluating these sources has been influenced by practical factors rather than specific

\footnotetext{
${ }^{4}$ Ilana Tahan, Memorial Volumes To Jewish Communities Destroyed In The Holocaust (London: British Library Publishing Division, 2004).
} 
geographical or historical parameters. Comparing these memorial volumes, however, might provide a valuable insight into the overall experience of Hungarian Jewish communities, which despite their different geographical locations seem to outline a similarly harrowing tale of persecution and expulsion. Finally, these six Hungarian yizker-bikher have not been subject to in-depth literary research before: their evaluation and interpretation is then not only an attempt at bridging a gap in knowledge but also a necessity in order to elevate the historical realities they report on.

The non-consecutive selection was largely limited by difficulties of accessibility, for which reason the volumes here are ones that have been previously digitised and are available within the online collections of the Yiddish Book Centre and the New York Public Library. The selection of primary sources was inspired by practical factors for which reason some of these localities are in the Eastern part of the country while others are in the mid-Western region. Two of them are county seats, one of them is a district in the Hungarian capital of Budapest, another two are smaller towns and one is a district seat. To clarify the geographical location and relation of these cities and their corresponding publications, a table (Figure 1) and map (Figure 2) are included: 
Figure 1: Studied Sources

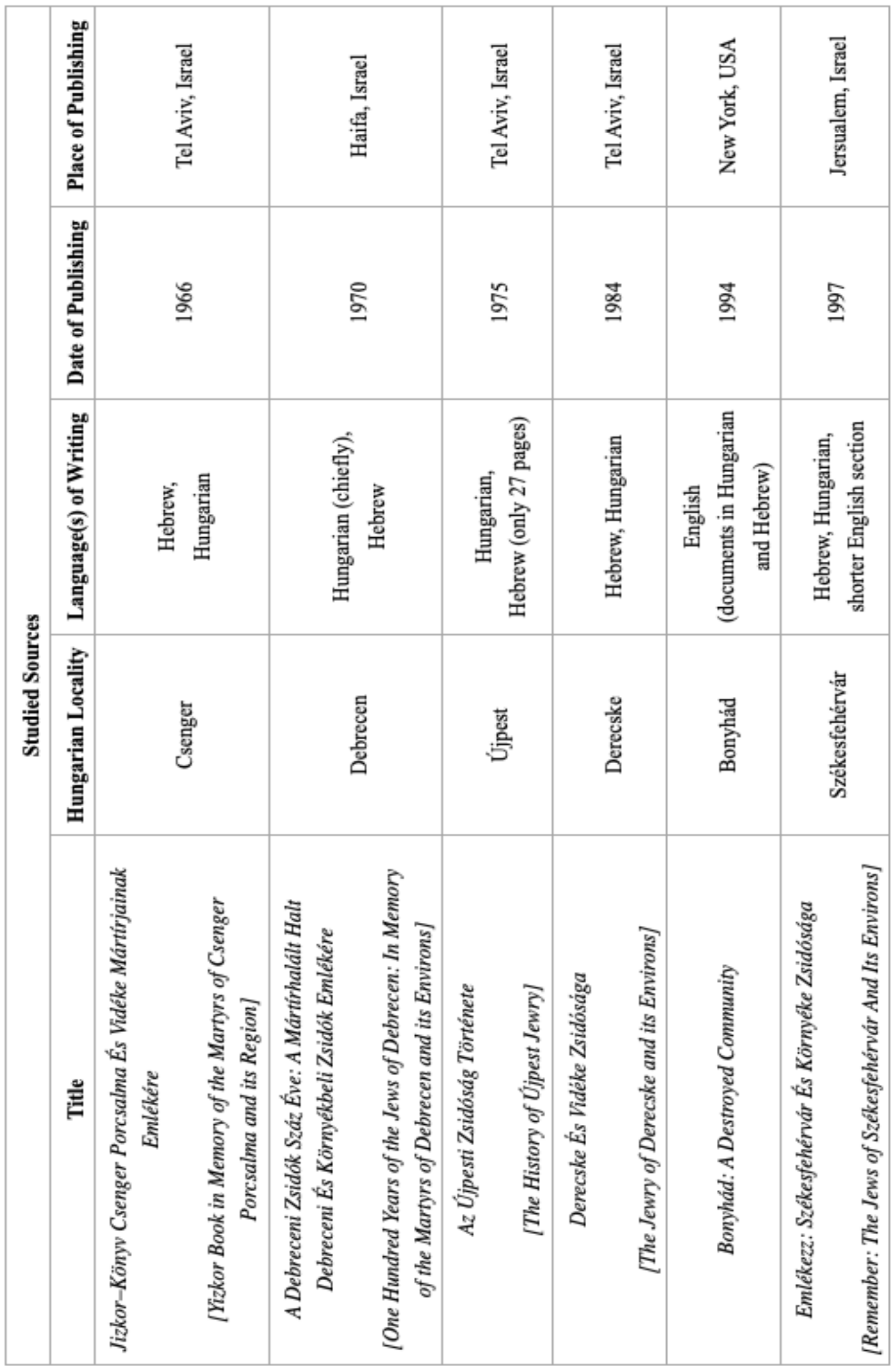




\section{Figure 2: Geographical Position and Classification of the Six Localities ${ }^{5}$}

\section{Hungary}

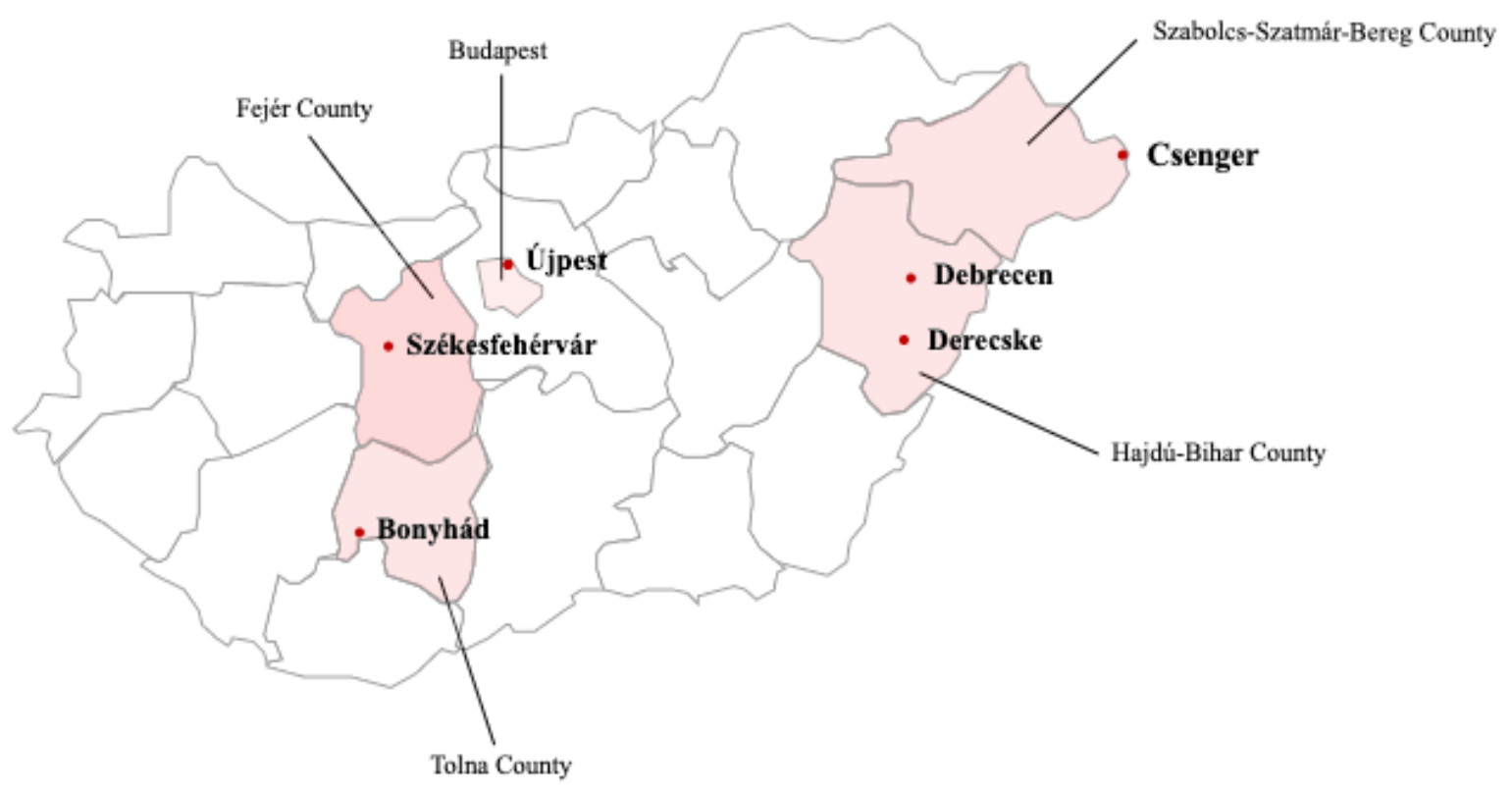

Bonyhád: District seat of Bonyhád District (Járás) in Tolna County

Csenger: Town in Szabolcs-Szatmár-Bereg County

Debrecen: Seat of Hajdú-Bihar County, second-largest Hungarian city

Derecske: Town in Hajdú-Bihar County

Székesfehérvár: Seat of Fejér County, ninth-largest Hungarian city

Újpest: 4th District in Budapest

\footnotetext{
5 The following map was created merely as a visual guide. For in-depth secondary sources on each location, see: László Kolta, Bonyhád A 18-20. Században [Bonyhád In The 18th-20th Century] (Bonyhád: Nagyközségi Tanács, 1975); Sándor Halmos, Szatmár Vármegye Zsidósága [The Jewry Of Szatmár County] (Nyíregyháza: Szabolcs-Szatmár-Bereg Megye Levéltára, 2008); Béla Siró, Debrecen Megpróbáltatásai [Debrecen's Tribulations] (Debrecen: Tóth Könyvkereskedés és Kiadó Kft., 2007); István Szendrey and Miklós Nyakas, Derecske Története [The History Of Derecske] (Debrecen: Derecskei Nagyközs. Tcs., 1980); Gyula Lauschmann, Székesfehérvár Története I - IV. [The History Of Székesfehérvár I-IV.] (Székesfehérvár: Székesfehérvár Város Leváltára, 1998); Imre Csabai and Ede Gerelyes, Újpest Története [The History Of Újpest] (Budapest: Közgazdasági és Jogi Könyvkiadó, 1977).
} 


\section{Yizker-Bikher as Linguistic Sources}

This first segment of the analysis will centre around Hungarian yizker-bikher as linguistic sources and their common narrative techniques. Evaluating yizker volumes based on their linguistic aspects and sources is dependent on many different factors, perhaps most importantly the decade in which a specific yizker-bukh [sing. memorial volume] was written. The style of these publications may vary a lot: while earlier ones tend to be written in Hungarian and Hebrew, or in some cases Yiddish, later ones are primarily written in English or Hebrew. Most of the earlier yizker-bikher were created as a community effort, for which reason these publications were likely to be in the language of the survivors and victims whose lives they aimed to commemorate. In order to understand the stylistics of Hungarian Jewish memorial volumes, it is worthwhile to do a textual examination of the language and narrative methods they are utilising. Though there are evident similarities, linguistic aspects of a given volume seem to influence their ability to convey 'objective' historical truth.

The books covered in this essay were commonly using an archaic, flowery Hungarian, often relying on religious scripture or the language of mourning literature (sefer) to achieve a more elevated tone. ${ }^{6}$ The date of these publications does not necessitate the archaic style they use, it is a stylistic choice rather than an adherence to contemporary linguistic practices. This is greatly exemplified by the introductory segment to Csenger's memorial volume, in which the first sentence likens the now perished members of the Jewish community to a 'living vista': 'Like a living vista, our former town, the Jewish community of Csenger, reappears in front of me...'7. The speaker-I then moves onto describing a once prosperous and deeply devoted community in which tradition served as the 'last bastion of defence' [védö bástya], protecting national and religious values, as well as continuity. This shows that the editor of this volume was a former member of the community, someone whose identity embraced both religion and a strong national belonging, someone who saw themselves equally Jewish and Hungarian at the same time. The language adopted here is romanticised and heavily reliant on the form of the literary anecdote, a great number of examples of former Jewish life are narrated as reimaginations of the devoted, frum ${ }^{8}$ Jew archetype:

A Jew who, an hour ago, was still immersed in the ordinary worries of making a living. And now on his way to the Temple, he looks forward with full anticipation to the reception of the great event, the "Queen of the Sabbath". ${ }^{9}$

The Jewish figure in this anecdote is an imaginary one, however, in the eyes of the narrator, he is not merely representative of the former community of Csenger but embodies it in his deep religiosity. This is a great example of how idealistic and pious the language is in certain volumes.

\footnotetext{
${ }^{6}$ Kugelmass and Boyarin, p. 2.

7 Slomo Friedmann, Jizkor-Könyv Csenger Porcsalma És Vidéke Mártírjainak Emlékére [Yizker Book in Memory of the Martyrs of Csenger Porcsalma and its Region] (Tel Aviv: Neografika Press, 1966), p. 4.

Original: 'Mint élő látkép elémtünik a mi volt városunk, a csengeri zsidó hitközség...'

${ }^{8}$ Yiddish adjective meaning observant, pious. In this context: devout orthodox Jew.

${ }^{9}$ Friedmann, p. 4. All forthcoming English language translations are my own unless otherwise indicated. For the Hungarian original, see Appendix 1.
} 
However, the reality of Csenger's Jewish community, as historiography shows, has been more complex and diverse: religious assimilation from the beginning of the $19^{\text {th }}$ century has widely affected the Jewish communities of Szatmár, the county in which Csenger is located. ${ }^{10}$ In his paper "'Memorial Books' As a Source for Research into the History of Jewish Communities in Europe" Abraham Wein argues that oftentimes 'the yearning for the past may cause the persons and figures to see in glittering colours'. In texts like Csenger's yizker-bukh then 'persons and figures are taken out of their natural context and presented to suit descriptions of Jewish tradition and way of life.'11

In later memorial volumes, language barriers often meant an issue for second- or thirdgeneration survivors, though there are Hungarian yizker-bikher created by second-generation émigrés or by the younger survivor generation who might have not had a grasp on the Hungarian language to the extent their parents or their grandparents did. This readership then would not be able to comprehend original Hungarian documents and is reliant on translation as a way to commemorate the former generations and their origins. Accordingly, some of the later volumes were written in English or Hebrew, often issued by American-Hungarian Jewish survivors and their children. From a comparative point of view, perhaps the greatest difference between the Hungarian and English journals is that the foreign language volumes tend to utilise a more simplistic, easily understandable language while older publications use an archaic style, similar to the case of the Csenger volume. This deliberate simplicity in the narrative techniques might be a result of the mediated, indirect reporting of experiences passed down to the next generations, as well as the urgency to reach a broader audience.

More coherent structuring is represented in the Bonyhád yizker-bukh. Though the volume was written and edited by former members of the community, it bears the stamp of the AmericanHungarian Jewish diasporic experience. Despite its effort to incorporate personal recollections, the language of this volume is less inspired by vivid emotional memory and is more reliant on archival documents and in-depth historical research. It also aims to provide a brief introduction to the Holocaust of Hungarian Jews, as well as situating Bonyhád's catastrophe from the aftermath of WWI to the time and place of the Arrow-Cross reign of terror. These stylistic choices might also be a result of the volume's more academic methodology in covering historical content. In order to illustrate the difference between the yizker-bukh of Bonyhád and the above introduced Csenger memorial volume, it is crucial to look at how the introduction to this second, younger yizker describes the pre-war Jewish community of Bonyhád:

In many parts of the country, especially in Trianon Hungary, the Jews called themselves "Magyars of the Israelite faith." A typical example of such a small community was that of Bonyhád, a relatively small town northeast of Pécs in Tolna County. ${ }^{12}$

This short introduction to the Jewish community highlights the fact that in this memorial

\footnotetext{
${ }^{10}$ Halmos, pp. 30-31.

${ }^{11}$ Abraham Wein, "Memorial Books' As a Source For Research Into The History Of Jewish Communities In Europe”, Yad Vashem Studies, 9 (1973), 255-272.

${ }^{12}$ Leslie Blau, Bonyhád: A Destroyed Community (New York: Shengold Publishers, 1994), p. 1.
} 
volume, despite providing insight into the community's everyday life and its former families, the focus is on the retelling of its history as one of the provincial towns that faced a common fate during the Hungarian Holocaust. Similarly to Csenger's publication, Bonyhád also highlights the fact that the local Jewry was a devoted and patriotic community, however, this is conveyed in a drastically different stylistic method than in Csenger's case. The author and historian behind Bonyhád's memorial volume is Leslie Blau, who in his introduction lists the extensive number of different organisations of Holocaust research who have helped him create the yizker. ${ }^{13}$ Overall, the style of this yizker-bukh mimics a historically accurate academic monograph rather than a sefer or pinkes: ${ }^{14}$ Though it speaks highly of the Jewry of Bonyhád it seems to be realistic on the community's size and influence. It is also important to note that this volume was originally published in English in 1994, and the Hungarian edition only came out in 2008. Interestingly, the original language of this community and the author have not been prioritised for mostly financial reasons among other hindering circumstances. ${ }^{15}$

The language of these volumes varies a lot, as outlined by the contrast of the two quotations above. Their stylistic achievements may range from more personal, casual entries to lengthier academic descriptions, oftentimes even within one volume Their material all aims to commemorate a formerly lively and culturally rich community, to pass down knowledge to future generations, as well as paying respect to the ones who have perished. The genre of memorial volume, therefore, exists as an object of continuity or 'agent of transmission' as Boyarin puts it: it bridges the gaps of memory the horrors of the Holocaust created and aims to restore a sense of origin and belonging in the ones who were bereaved of it. ${ }^{16}$ This effort is then reflected differently in the linguistics of these publications, some prioritising a more embellished, religious tone, others focusing on a clearer, less subjective narration. These differences in linguistics, style and even covered material ensure that the volumes altogether constitute a constellation of memory. Yizker-bikher are united by their effort at evoking and shining light on the fate of unique Jewish communities, each different yet part of one Hungarian Jewish history, like stars in a constellation.

\footnotetext{
13 Joshua Shanes, "Memorybooks", p. 446.

${ }^{14}$ Kugelmass and Boyarin, p. 2.

${ }^{15}$ For more on the Hungarian translation see: László Blau, Bonyhád: Egy Elpusztított Zsidó Közösség (Bonyhád: Soha többé SOA Alapítvány, 2008), pp. 5-6.

${ }^{16}$ Kugelmass and Boyarin, p. 35.
} 


\section{Hungarian Holocaust History Depicted}

The following section moves onto analysing the ways in which Hungarian Holocaust history is discussed and depicted in the six volumes, focusing on the historical material they cover. Since yizker-bikher were usually created and edited by landsmanshaftn, the course of Hungarian history retold is written from the viewpoint of the many, utilising the collective voice of its varying authors. A great example of this type of storytelling is the 1997 Székesfehérvár memorial volume. This yizker was published not only as a multi-author project but also as a multilingual one: it includes a Hungarian, English, and Hebrew language translation within the one volume. As the previous paragraph has explained, earlier yizker-bikher tend to follow a more literary approach, while the later publications mimic historical monographs in their narrative methodology and linguistic style.

These more scholarly yizker-bikher often have to tackle the loss of original archival data and available material, including crucial legal documents or photographs. This disadvantage is usually addressed in the introduction, claiming that the gaps in chronology are filled in throughout the book, like in the case of the Székesfehérváryizker-bukh. In most cases, however, narration centres around the demographic and religious changes in the given community, which is likely to be supported by primary material from the town's archives or gathered family documents. Kugelmass and Boyarin argue in their book From a Ruined Garden: The Memorial Books of Polish Jewry, that most Polish volumes are set to report history correctly even in the cases where there are no historical sources provided. ${ }^{17}$ They argue that the chronology and demography listed in these books is nearly always plausible and can be supported by contemporary historical research. Similarly, this attempt at a general, factual accuracy can also be observed in the case of Hungarian memorial volumes. Their content is in most cases organised by a general chronology of events, though this chronology rarely plays a crucial role in the narrative. Personal stories, experiences, and memories are prioritised over the reporting of general historical facts and available data.

All six of the covered volumes share the same methodology when introducing the community they commemorate. Their first chapters tend to explain the roots and origins of the given Jewish community, detailing how and why settlers ended up in the region and in that specific village or town. Some, especially the earlier volumes also include elaborate descriptions of Jewish life during the editors' time in the community. These lengthier descriptions of family history, name origins or changes; or occupational patterns are often very similar to each other in the way in which they are structured and discussed, even when the size of the communities had differed massively. Demography seems to show very similar tendencies divided between provincial towns and the bigger localities of Újpest, Debrecen and Székesfehérvár. The six memorial volumes report on similar professions, familial relations and alternative religious identity patterns, depending on whether they described a rural or urban community. Smaller village life usually centred around the prayer house, the Jewish school (if there was one in the area) and some sort of industrial building or courtyard. The Derecske memorial volume has the following observations on Jewish occupational models and how they 'served' the majority

\footnotetext{
${ }^{17}$ Kugelmass and Boyarin, p. 40.
} 
gentile demographic:

The trade was largely in Jewish hands: spice shop, haberdashery, building materials, hardware. They [the Jews] provided the village with all these necessary items. Even the funeral service was theirs. [...] What else was in Jewish hands? Well, the tavern. And when did the goy not drink? Morning, evening, winter and summer, in his joy and sorrow, whether he had money or not, he did nothing but drank. ${ }^{18}$

The segment above exemplifies how history is incorporated into the more personal, casual, even humorous style of the memorial volumes. It visualises Derecske as a rural space in which Jewish life accommodated gentile needs and vice versa. Haberdashery and trading seemed to be the most common occupations filled in by the members of the Jewish community in the smaller, rural towns like Derecske. ${ }^{19}$ Life was slower, the urgency of social issues was not as wellreported as for example in the Újpest volume. Since Újpest was close to the city centre of the capital, its relationship to big city life and its politics was direct. The yizker-bikher reports of urbanisation patterns within the Jewish communities of the smaller towns: the pull of urbanite city life seemed to be promising for the Jewry of these often-secluded towns and villages. Jews from the countryside had started to urbanise and move to bigger cities by the beginning of the nineteenth century: the Székesfehérvár volume reports this process concerning the surrounding agglomeration of the city, with a specific detour on the neighbouring village of Lovasberény:

The pull of large cities eventually resulted in the decline of the village's Jewish community. Moreover, in 1878, the Chevra Kadisha [Burial Society building] burned down with all its equipment including the community documents. ${ }^{20}$

This segment highlights the difficulty of research while creating the volume, due to the burning down of the Chevra Kadisha. The Székesfehérvár and Debrecen volumes are great reference points to draw out the contrast between urban and rural life: cities had their separate occupational models, more representative of middle-class existence. The Jews of újpest have been occupied in many well-paying positions, including as lawyers, academics and doctors. ${ }^{21}$ Despite the differences between the Jewry of villages and cities, all volumes report of the continuously growing antisemitism of the 1920s with deep horror and grief, listing a long list of names of the ones deported, killed, or disappeared. Memorial volumes spend a lot of time listing these names and, in certain cases, they provide photographs of families, of important people, or even buildings that were destroyed during the war. Some volumes assume the reader's familiarity with the historical events anticipating the anti-Jewish climate. The

\footnotetext{
${ }^{18}$ Árje Moskovits, Derecske És Vidéke Zsidósága [The Jewry of Derecske and its Environs] (Tel Aviv: A derecskei gyülekezet maradéka, 1984), p. 15. See, Appendix 2.

${ }^{19}$ István Szendrey and Miklós Nyakas, pp. 185-191.

${ }^{20}$ Eliezer Dr Even, Emlékezz: Székesfehérvár És Környéke Zsidósága [Remember: The Jews of Székesfehérvár And Its Environs] (Jerusalem, 1997), p. 20. See Appendix 3.

${ }^{21}$ Szilágyi-Windt, László, Az Újpesti Zsidóság Története [The History of Újpest Jewry] (Tel Aviv: Lahav, 1975), p. 239.
} 
Debrecen volume references the Numerus Clausus ${ }^{22}$ - an article of law enacted in 1920 aiming to limit the number of Jewish students accepted into higher education, without any explanation of what the law meant or how it came about. ${ }^{23}$

Most descriptions of the interwar period rely on personal testimonies of growing antisemitism with little reference to legal changes or contemporary political events. Most volumes mention the Horthy era and its White Terror as fundamental sources of growing antisemitic hatred, though these descriptions are usually kept brief. This might be the result of a strong reliance on the readership's in-depth understanding of mainstream historical events, as well as the survivors' limited engagement with contemporary politics in their testimonies. 'New laws every day, yet we naively believed in Horthi's [sic] Hungary', the Csenger volume reports. ${ }^{24}$ The Horthy regime's political propaganda had severely tainted the Jewish public's ability to realise the true danger they were subject to. Horthy had promised to refuse the deportation of Hungarian Jews at all cost, a false promise he would eventually break when ordering the Hungarian army not to resist German occupation.

A few yizker-bikher include lengthier introductions to the course of the Hungarian Holocaust and contemporary Hungarian politics. These volumes tend to be the later ones: the Bonyhád yizker gives a more detailed explanation on Miklós Horthy's decision to appoint Kállay as prime minister, while the one from Derecske more generally mentions the growing antisemitism of post-WWI Hungary. According to its editor, Jewish demise was directly linked to the presence of German military forces throughout Hungary, outlining Hungary's loss in WWI as the root of Jewish deportations and the Hungarian Holocaust. ${ }^{25}$ Contrasting this to modern historiography, it is important to see Hungary's complicity in the organisation of deportations and the public's hostile treatment of Jews both in cities and especially in rural areas. ${ }^{26}$

As Abraham Wein states, most of the volumes tend to focus on modern, contemporary history just before, during and after the war, yet there are significant differences in their reporting. The histories told by the six volumes vary in focus and scope, as linked to their geographic context, demography, and infrastructure. They differ in their attempt to retell the story of their communities, as well as in their communal priorities. The history depicted in these volumes then ranges from personal testimonies to general descriptions of mainstream Hungarian Holocaust history.

\footnotetext{
${ }^{22}$ For more on the historical consequences of Numerous Clausus refer to: Viktor Karády and Péter Tibor Nagy, The Numerus Clausus In Hungary (Budapest: Pasts Inc. Centre for Historical Research, 2012).

${ }^{23}$ Moshe Elijahu Gonda, A Debreceni Zsidók Száz Éve: A Mártírhalált Halt Debreceni És Környékbeli Zsidók Emlékére [One Hundred Years of the Jews of Debrecen: In Memory of the Martyrs of Debrecen and its Environs] (Haifa: Debreceni Zsidók Emlékbizottsága, 1970), p. 115.

${ }^{24}$ Friedmann, p. 57.

${ }^{25}$ Moskovits, p. 70.

26 Ibid.
} 


\section{The Historical Veracity of Memorial Books}

This final and concluding segment will discuss the historical accuracy of yizker-bikher with reference to their previous use and altering perspectives on their ability to convey historical truth. Academic views on whether yizker-bikher make valuable historical sources have been continuously changing since the 1950s and the first historical reviews of such volumes. The first generation of historians ever to discuss the books from this angle, including Abraham Wein and Jacob Szacki, have found yizker-bikher to be questionable both in content and style. In “'Memorial Books' As A Source For Research Into The History Of Jewish Communities In Europe", Wein argues that since yizker volumes were often the products of community effort, containing different, often unexplored sources, their ability to convey historical truth is significantly mitigated. Similarly to transcriptions of oral history recorded from 1945 onwards, the content in these publications tends to focus on personal and community experiences rather than the uncovering of 'objective' historical truth. Finding documentation of atrocities during and before the war proved to be an especially challenging task for some of the yizker editors. This was the case in Derecske, as well as Debrecen, as previous paragraphs show. Naturally, in the case of smaller locations such as villages and shtetls, archival material is even more difficult to uncover.

Earlier historians tend to agree that yizker volumes cannot be categorised as primary sources, as it is traditionally used in historiography, 'that is, they are not contemporaneous documents that have been passed down to us intact.'27 The people who wrote and edited these volumes were in most cases not historians, their aim was simply to commemorate their dead in a written form that was preservable. Importantly, the job of yizker editors was a difficult one: it was their responsibility to decide which photographs, letters, and personal stories would make the cut to be included in the final, published volume. Wein and his contemporaries argued that most of the volumes are indeed poorly edited and include stories without providing sources or evidence of their veracity. According to Jacob Szacki, editorial efforts are lacking when it comes to organising the material the yizker volumes cover: 'In general there is no editorial hand to be seen. Everything is vague, chatty, and unverified...'28 In the case of the Hungarian volumes, the expectation of academic accuracy and fastidious editing might limit the ways in which these sources could be utilised. The environment of the smaller, rural Jewish communities of Csenger or Derecske came with a different set of priorities and foci than what this early generation of scholars understood to be relevant or valuable for historical study. This, however, should not render these texts invaluable as they open up the possibility for other methods of interpretation.

Szacki also observes that since there was no way to tell whether the stories the narration operates with are 'objectively true' or not, editors could have manipulated the material in ways that suited their personal views and experiences. Moreover, as these volumes go through the

\footnotetext{
${ }^{27}$ Jack Kugelmass and Jonathan Boyarin, "Yizker Bikher and the Problem of Historical Veracity: An Anthropological Approach" in The Jews of Poland Between Two World Wars, ed. by Yisrael Gutman, et al., (Hanover: Brandeis University Press, 1989), pp. 519-536, (p. 519).

28 Jacob Szacki (Shatzky), "Yizker Bikher", YIVO Bleter 39 (1955), p. 351.
} 
process of the community commissioning, writing, and eventually editing for itself, the information shared is often self-referential and in cases only explicit in meaning to the members of the given community. For this reason, certain yizker-bikher have not been reviewed or researched at all..$^{29}$ This is also the case with the six volumes covered in this essay. These yizkerbikher rely heavily on personal memories of important persons, interactions with other members of the community, or more subjective retellings of events as the bases of their narratives. For this reason, it is difficult to find in them the 'objective historical truth' Szacki, Wein and their contemporaries were looking for. This expectation of objectivity, however, might not be the most optimal way of approaching these texts, as shown in the following chapter.

Though later yizker volumes tend to mimic historical monographs both in their stylistic and research methods, these volumes often lack the personal insight and multiperspective nature of the earlier publications. Arguably, what these volumes have to offer in their ability to report history, they lack in diversity as linguistic or anthropological sources. Scholars from the 1970s onwards have reevaluated the importance of memory books with special attention to their use for the study of Jewish culture and tradition. This next generation of historians have often excluded monograph-style yizker volumes for not fitting the requirements of multiperspectivity and communal authorship. ${ }^{30}$ According to contemporary voices, like that of Rosemary Horowitz, the personal touch and intimate atmosphere yizker-bikher can offer their readers might be the most important perspective when it comes to their use in historiography. ${ }^{31}$

As views on what constitutes a valuable source for historical research has developed, academic views on yizker volumes have also changed from dismissive to more appreciative. Though the volumes have received growing attention in the past few years, many of them have still not been subjected to any sort of research or evaluation. These memorial books are often the ones which are not well-translated and are written in languages read by few people, such as Yiddish or Hungarian. Issues with linguistic accessibility then further limit the ways in which these sources are, or can be, utilised. In order to encourage translation, academic, and public use, The New York Public library, in collaboration with the Yiddish Book Center, has digitised over six hundred and fifty memory books in an effort to make them more readily available. This institutional effort might help these valuable publications to receive broader attention. ${ }^{32}$

\footnotetext{
29 Joshua Shanes, "Memorybooks", pp. 446-450.

30 Joshua Shanes, "Memorybooks", p. 446.

${ }^{31}$ Rosemary Horowitz, "Introduction", in Memorial Books Of Eastern European Jewry: Essays On The History And Meanings Of Yizker Volumes (Jefferson, North Carolina: McFarland, 2021), pp. 1-4.

32"Yizkor Books", Yiddish Book Center, <https://www.yiddishbookcenter.org/collections/yizkor-books> [Accessed 25 April 2021].
} 


\section{Conclusion}

The archival, factual histories of the six different geographical locations discussed in this essay are, on the whole, well-researched and documented. This might be due to the fact that none of the communities discussed here are particularly small; they are considered to be relevant settlements in Hungarian geography to this date. Moreover, both Jewish and gentile communities prioritised the documentation of births, deaths, leadership, or infrastructure changes within their respective groups. Despite the already-existing data, there is research potential in these volumes too, as testimonial literature adds different layers of historicity; it provides a personal layer, personal testimony to archival research. Researching memory books to find historical evidence is useful, considering their ability to offer personal, as well as collective accounts from historical loci that are only covered in archives and encyclopaedias. Piecing these different localities together helps to outline what certain parts and communities of the country looked like, what Jewish people struggled with in these regions, both emotionally and socially. Yizker-bikher highlight the gaps in mainstream, common historical memory, creating microhistory on their own. Their building blocks are perhaps the smallest elements of what has constituted the Hungarian Holocaust. From a more linguistic and literary point of view, yizker-bikher are an important link in the chain of religious and folkloristic tradition. As shown in previous paragraphs, these books utilise a mixture of religious, historical and conversational elements and can often feel like recordings of oral history, covering a layer of life that historical monographs might not be able to convey, including personal loss, human emotions and other depths of survivor testimony. Yizker-bikher were written to preserve a legacy forcefully terminated, and to remember the community, never claiming to be unbiased sources of history. Their approach is admittedly more focused on emotional tragedies and personal histories rather than overarching solutions to what happened and why. The six volumes covered here do not uncover 'unknown' historical data, but they do reinforce the veracity of the sources they refer to.

Kugelmass and Boyarin argue that yizker-biker ought to be read as anthropological source texts, rather than historical ones, which might be a helpful way to conceptualise their use. Yizker-bikher, after all, are not meant to be academic discussions on a certain time and era, they are attempts at preserving the legacy and memory of victims and survivors. In the case of the Hungarian volumes, their research proves to be important as they remind their readers of Hungarian complicity and responsibility in organising the deportation and ghettoisation of the Hungarian Jewry. They bear witness to communities that were depopulated and destroyed, communities that are still actively mourning their former members, communities that left a significant cultural impact on their countries and gentile neighbours. These six volumes provide evidence both against ignorance and Holocaust denial, highlighting the inaccuracy of denying Hungarian complicity in the Holocaust which proved to be a recurring rhetorical weapon during the last ten years of Hungarian politics. ${ }^{33}$

The above analysed yizker volumes show a variety both in style, material covered, and

\footnotetext{
33 Ferenc Laczó, "New Sensibilities, New Volatilities: Antisemitism In Contemporary Hungary", Antisemitism Studies,
} 2.1 (2018), 75-108 <https://www.muse.jhu.edu/article/718382> [Accessed 25 April 2021]. 
approach to content. The selected Hungarian publications are also contrasting in the type of communities they discuss, including smaller, rural Jewish communities, larger urban Jewish communities, poorer and richer areas. From a linguistic point of view, earlier yizker-bikher are worthy of research if not most importantly as historical texts, but from an anthropological and literary perspective. These sources are diverse in the ways in which they choose to remember communities perished during the Hungarian Holocaust. In conclusion, though the historical veracity of the selected six yizker-bikher might not match primary archival material, these volumes are likely to offer several layers of personalised meaning that compliments such primary sources. Memorial volumes are artefacts of memory embracing communal imagination and individual remembrance, creating an intimate past unknown to many studying the Holocaust. 


\section{Bibliography}

Blau, László, Bonyhád: Egy Elpusztitott Zsidó Közösség (Bonyhád: Soha többé SOA Alapítvány, 2008)

Blau, Leslie, Bonyhád: A Destroyed Community (New York: Shengold Publishers, 1994)

Csabai, Imre, and Ede Gerelyes, Újpest Története (Budapest: Közgazdasági és Jogi Könyvkiadó, 1977)

Dr Even, Eliezer, Emlékezz: Székesfehérvár És Környéke Zsidósága (Jerusalem, 1997)

Dr Szilágyi-Windt, László, Az Újpesti Zsidóság Története (Tel Aviv: Lahav, 1975)

Friedmann, Slomo, Jizkor-Könyv Csenger Porcsalma És Vidéke Mártírjainak Emlékére (Tel Aviv: Neografika Press, 1966)

Gonda, Moshe Elijahu, A Debreceni Zsidók Száz Éve: A Mártírhalált Halt Debreceni És Körynékbeli Zsidók Emlékére (Haifa: Depreceni Zsidók Emlékbizottsága, 1970)

Halmos, Sándor, Szatmár Vármegye Zsidósága (Nyíregyháza: Szabolcs-Szatmár-Bereg Megyei Önkormányzat Levéltára, 2008)

Horowitz, Rosemary, Memorial Books Of Eastern European Jewry: Essays On The History And Meanings Of Yizker Volumes (Jefferson, North Carolina: McFarland, 2021)

Karády, Viktor, and Nagy, Péter Tibor, The Numerus Clausus In Hungary (Budapest: Pasts Inc. Centre for Historical Research, 2012)

Kolta, László, Bonyhád A 18-20. Században (Bonyhád: Nagyközségi Tanács, 1975)

Kugelmass, Jack, and Boyarin, Jonathan, From A Ruined Garden: The Memorial Books Of Polish Jewry (Bloomington: Indiana University Press, 1998)

Kugelmass, Jack, and Boyarin, Jonathan, 'Yizker Bikher And The Problem Of Historical Veracity', in The Jews Of Poland Between Two World Wars (Hanover: Brandeis University Press, 1989)

Laczó, Ferenc, 'New Sensibilities, New Volatilities: Antisemitism In Contemporary Hungary', Antisemitism Studies, 2 (2018), 75-108

Lauschmann, Gyula, Székesfehérvár Története I - IV. (Székesfehérvár: Székesfehérvár Város Leváltára, 1998)

Moskovits, Árje, Derecske És Vidéke Zsidósága (Tel Aviv: A derecskei gyülekezet maradéka, 1984) 
Shanes, Joshua, 'Memorybooks' in The Routledge Companion To Jewish History And Historiography (London: Routledge, 2018)

Siró, Béla, Debrecen Megpróbáltatásai (Debrecen: Tóth Könyvkereskedés és Kiadó Kft., 2007)

Szacki (Shatzky), Jacob, 'Yizker Bikher', YIVO Bleter, 39 (1955)

Szendrey, István, and Nyakas, Miklós, Derecske Története [The History Of Derecske] (Debrecen: Derecskei Nagyközs. TCs., 1980)

Tahan, Ilana, Memorial Volumes To Jewish Communities Destroyed In The Holocaust (London: British Library Publishing Division, 2004)

Wein, Abraham, "Memorial Books" As A Source For Research Into The History Of Jewish Communities In Europe', Yad Vashem Studies, 9 (1973)

Yiddish Book Center, <https://www.yiddishbookcenter.org/collections/yizkor-books> 


\section{Appendix}

1. Egy zsidó aki egy órával ezelőtt még el volt merülve a megélhetés hétköznapi gondjaiba. És most útjába a Templom felé, teli várakozással néz elé a nagy eseménynek, "Szombat Királynőjének" a fogadtatására.

2. A kereskedelem nagyrészt zsidókézen volt: füszerüzlet, rőfösbolt, építőanyag, vasárú. Mindezekkel a szükséges cikkekkel ők látták el a falut. Még a temetkezési vállalat is az övék volt. [...] Hogy mi volt még zsidókézen? Hát a korcsma. S mikor nem ivott a gój? Reggel, este, télen-nyáron, örömében és bánatában, akár volt pénze, akár nem, ő mindig csak ivott.

3. A nagyvárosok vonzásában mégis egyre csökkent a falu zsidósága, sőt még sorscsapások is siettették a helyi közösség sorvadását. 1878-ban leégett a Chevra Kadisha épülete, benne veszett a felszerelés és a hitközség összes dokumentuma. 